\title{
Decolonizing Diaspora: Whose Traditional Land Are We On?
}

\author{
Celia Haig-Brown \\ York University \\ haigbro@edu.yorku.ca
}

\begin{abstract}
As a way to consider the possibility of decolonizing discourses of diaspora, the central question posed in this paper asks not only where do people of the diaspora come from, but where have they come to? In North America, nations have been superimposed on Indigenous lands and peoples through colonization and domination. Taking this relation seriously in the context of discourses of race, Indigeneity and diaspora within university classrooms interrupts business as usual and promises a richer analysis of one particular similiarity amongst diasporic, as well as settler, groups in North America with possible implications beyond this context. In short, the author asks each reader to respond to the question, "Whose traditional land are you on?" as a step in the long process of decolonizing our countries and our lives. While part of the focus for this paper is on theorizing diaspora, there are obvious implications for all people living in a colonized country. Drawing primarily on three pedagogical strategies and events arising from them, the author takes up some of the possibilities for theory-building that they suggest. Reflections on courses taught, student feedback and texts from Toni Morrison's Playing in the Dark to James Clifford's "Indigenous Articulations" ground the discussion.
\end{abstract}

\section{Introduction: Whose Traditional Land?}

Let us begin at the beginning: if we take seriously anyone's responsibility to consider whose traditional land they dwell in, we might begin with ourselves. As I write, I am located on land that Indigenous ${ }^{i}$ peoples have occupied and travelled since time immemorial and that they continue to occupy and travel now with peoples from many other nations. This particular space has come to be known as the traditional land of the Mississauga: at least those are the people whose signatures (Canada 1891:36) are represented on the several questionable treaties and illegal real estate deals that allowed the transfer of "ownership"ii of the land (Schmalz 1991:125) iii either directly to settlers or eventually to them through the government's acquisition. For many Indigenous peoples the concept of land ownership is and was foreign to their ontologies: land is never owned. Rather it is a spiritual and material entitity to be treasured and cared for as a relative for all those generations of beings who will follow.

When the final cession at the mouth of the Credit River near what is now called Toronto, Ontario, Canada was made, the remaining Mississauga people in this part of Southern Ontario were ironically "given" a piece of land that had, years before, been "sold" by their relatives to the British for the Six Nations people who were being rewarded for their support of the British in the war with the Thirteen Colonies. ${ }^{\text {iv }}$ (Canada 
1891:22-25, Dickason 1992:86-87) Additionally, the land was originally occupied by the Neutral, Petun, and the Wendat (Dickason 65, 70, 130, 434) who years earlier had been replaced by the Anishinaabe. This area was so rich in animal and plant life that, for generations, it has served as a land of plenty for the many peoples who travelled and lived here at different times of each year. ${ }^{\mathrm{V}}$ In EuroCanadian parlance, this land has a humid, continental climate, numerous rivers and tributaries running into the Great Lakes to the south and west and an annual percipitation of 83 centimenters. Since long before it was disrupted by cities and sprawling suburbs, this land was and continues to be ${ }^{\mathrm{vi}}$ a gathering place of Indigenous peoples with "complex histories of dwelling and travelling...Everyone's on the move and has been for centuries: dwelling-in-travel" (Clifford, 1997:2). For this article, the lands under discussion lie primarily within the nations now called Canada and the United States of America. That being said, for those who care to make the connections, there are implications of this discussion for colonized lands and Indigenous peoples around the globe.

As a way of focusing this article, I consider the possibility of decolonizing discourses of diaspora, by asking the central question not only where do people of the diaspora come from, but where have they come to? In North America, nations have been superimposed on Indigenous lands and peoples through colonization and domination. Taking this relationship seriously in the context of discourses of race, Indigeneity and diaspora interrupts business as usual and promises a richer analysis of one particular similiarity amongst diasporic, as well as settler, groups in North America with possible implications beyond this context. In short, I ask each reader to respond to the question, "Whose traditional land are you on?" as a step in our long processes of decolonizing our countries and our lives. While part of the focus for this paper is on making a small contribution to theorizing diaspora, there are obvious implications for all people living in a colonized country. Drawing primarily on three pedagogical strategies and events arising from them, I take up some of the possibilities for theory-building that they suggest. Reflections on courses taught and texts from Toni Morrison's Playing in the Dark to James Clifford's "Indigenous Articulations" ground the discussion.

\section{Nigglings and Theorizing about Diaspora}

Over time, this essay has struggled onto the page in a respectful effort to question a particular aspect of theorizing diaspora and through that question to make a contribution to furthering thought in the area. Evolving directly from teaching events and arising with my conviction of the need for such intervention in current theory-building, the hope remains that it will speak in good ways to those readers who are prepared to respond to the plea embedded in and articulated through the interrogation. The idea for the focus of the article originated with a niggling sensation, the perception of an absence in theorizing Diaspora, and a hesitation at pointing to that absence because of my limited work in the area. It has provided an opportunity for me to read critically in the area of diasporic studies as I tried to place my pedagogical observations within a deeper understanding of the significance of the theorizing that so many committed scholars have been thinking through and conceptualizing. This article exemplifies a form of grounded theory building in that its impetus lies in everyday practice while the synthesis it attempts seeks to inform existing theorizing as well as pedagogical practices. 
Following Clifford, I take up the notion of Diaspora as involving "a history of dispersal, myths/memories of the homeland, alienation in the host (bad host?) country, desire for eventual return, ongoing support of the homeland, and a collective identity importantly defined by this relationship." (1997:247) Typically such discourse begins with the Jews dispersed out of Palestine (following the Babylonian captivity) (Braziel and Mannur 2003; Werbner 2000:12). A second commonly cited discursive instance of the word Diaspora (sometimes with the capital removed) is as an expression of the material reality of millions of West Africans captured and transported as slaves between 1502 and 1865 by White European exploiters (Brand 2001; Mirzoeff 2000). In its current expanding definition, Diaspora may be used to speak of any people who have (been) moved from a homeland, often cannot return to that homeland, and are living in a new and different space, sometimes within a group of people with similar histories, always with an attachment to that other place of origin (Clifford 1997; Werbner 2000). Indentured labourers serving capitalist expansion over the last two centuries; refugees from a range of civil wars often exacerbated by outside influences still related to the expansion of capital and global markets; and people seeking safe havens from a range of inhuman experiences in their countries of origin are only a few of those included in at least some current understandings of diasporic studies.

A edited collection published by Blackwell points to the contemporary importance of Diaspora Studies as twofold: "First, diaspora forces us to rethink the rubric of nation and nationalism, while refiguring the relations of citizens and nation-states. Second, diaspora offers myriad, dislocated sites of contestation to the hegemonic, homogenizing forces of globalization" (Brazial and Mannur 2003:7). Ultimately and most poignantly, I seek discursive consideration in diasporic studies not only of people's movement or dispersal and the homeland from which they have come, but of the lands and histories of the people in the places where they arrive. I concur with Clifford that if diasporic theory is to "travel well" in First Nations contexts, "there needs to be a significant adaptation to a different map and history." (2001:483) In relation to the Indigenous peoples of North America, keeping history and current issues visible, particularly land claims - as these refigurations and contestations develop - is paramount. It does seem to me that the tenets of Diaspora - particularly as they continue to shift and develop-deserve to be interrogated regarding their applicability for theorizing First Nations and Aboriginal situations. ${ }^{\text {vii }}$ This claim remains for investigation in another paper.

\section{Decolonizing Education Courses}

Three pedagogical events led me to focus on this interrogation of the notion of Diaspora. The first is a student's story from a preservice teacher education course; the second, central to the paper's argument, arose in a team teaching situation in a doctoral seminar; and the third event is expressed in a graduate student's work following a course called (de)colonizing Research Methods. All three events occurred in relation to courses I regularly teach. Each provides a focus for thinking through the theoretical constructs within which I organize my thoughts and my pedagogical work as a teacher/professor of Education. Foundations of Education was one of the required courses in our preservice teacher education program: it typically encompasses disciplines such as history, 
philosophy and sociology and their relevance to education. We consider the history of education in Canada - which in previous iterations of the course most often began with schooling for the settlers' children; the sociology of education started with works such as Paul Willis's Learning to Labour or Bowles and Gintis's Schooling in Capitalist Society; the philosophical focused on concepts and their meanings. Some professors use the course to introduce Freudian or other pet theories and their implications for pedagogy.

In my course for preservice teachers, as in all my courses, I have come to insist that considerations of education and research in Canada begin by taking seriously the land and Indigenous people. I tell my keen students on their first day that the foundations of Canadian education are land and Aboriginal people. They listen dutifully and at first without question. We look to traditions and history. Acknowledging the first peoples of this land and their experiences of education can serve to lead the students to a clearer and deeper understanding of what was and is at stake in schools and the broader society today. While some students resist such considerations as passé, most find their understandings of schooling and the impact of the assimilationist policies practiced over the years into the present day deepen as they come to know the complex histories of schools and Aboriginal people. Land claims, the Indian Act, treaties, tuition agreements all become part of the discussions of schools in Canada. Student teachers become more prepared to take up the complexities of working with peoples from a range of histories and origins as they begin to see their relation to Aboriginal peoples - and some of the teachers are, of course, Aboriginal themselves. (A similar approach would serve well in other nations created through the process of colonization, particularly the intensive brand that accompanied the Industrial Revolution's unbridled greed for resources and labour in the quest for profit.) $)^{\text {viii }}$

In the foundations class, the history (and pre-written-history) of education in Canada begins with traditional education embedded in the everyday lives of members of the varied Aboriginal cultures and nations across the continent. In traditional forms of education, children, their parents and grandparents engaged in a lifetime of watching, learning and doing: no separation of any age group from this active participation in learning within the community occurred. Traditionally, in everyday practices, as their abilities develop, students, no matter what their age, begin doing what they are able to do. Whether it involves cleaning a fish or taking responsibility for a ceremony, learning is continuous. Commitment to lifelong learning - now a focus in theorizing and promoting adult education-is hardly a new concept in such contexts. Before contact with Europeans, there were no school buildings per se although, on occasion, people spent (and may continue to spend) time in isolation from others for particular ceremonies and practices. In many communities, these practices persist to one degree or another.

In research and graduate teaching that I did with First Nations women in British Columbia in the late 1990s, one of the students talked of ceremonies for young women reaching puberty, at which time they are removed from school for several days to spend time learning traditional ways with the older women. A non-Aboriginal graduate student in the same class, who had taught at the school being discussed, commented in amazement about having wondered where the young women in his village school went and only realizing at that moment what had been happening.

In North America, schooling - or what has been ethnocentrically called formal education - began as a relation between Europeans and Indigenous people. The initial 
efforts appeared fairly innocuous with missionaries selecting a "privileged" few students, usually boys, to participate in classes either on this continent or in Europe (Miller 1996:39). ${ }^{\text {ix }}$ Most of us know that schooling fairly quickly became a major tool for attempted assimilation of First Nations peoples into that cheap source of labour demanded by the marketplace mentality of the early colonizers of what we now call Canada. ${ }^{\mathrm{x}}$ Too frequently, these roots of contemporary schooling are conveniently forgotten along with the colonial mentality that continues to inform this studied amnesia. If mainstream teacher education can continue to forget about Indigenous peoples, there will be no more call for justice to be done for the fifty-five founding nations of this country - nations that may have been intentionally involved in the establishment of Canada or coerced, forced or tricked into compliance. What does this mean for people of the diaspora who find themselves living in Canada?

At one point in this course, a Black student who had come to Canada from Jamaica as a teenager spoke with me about what she had been learning about her own existence in Canada as the course unfolded. In our conversation, she began by describing her arrival in Canada, saying that almost the moment she went out into the streets, she found herself sinking into a major depression. In therapy, later in her life, she identified her first traumatic experiences of racism as the root cause. In Jamaica, of course, as a member of the majority, she did not experience this direct onslaught of racism. As she read and heard about First Nations experiences in the class, she said she felt as if she were beginning to understand much more clearly the sets of colonial relations underpinning the racism she faced. Previously, she said, she had "always seen racism in Canada as a black and white thing." After reading Roxana Ng, Isabel Knockwood, and others and participating in class discussions, she began to see the complexity and depth of what she faced. Knockwood details her experiences of residential school and its continuing impact on the lives of herself, her family, and her friends. The assault on her Mi'kmaw spirituality, culture, and language are wounds still healing. She writes, "Many years will have to pass before the damage inflicted by the Residential School can be healed. I am still dealing with the mentally, emotionally and spiritually damaged child of five...It makes no difference that government officials and some representatives of the Catholic church have apologized to Native people for the schools" (Knockwood 1992:158). For the student teacher, this work spoke not just to Knockwood and her family's need for healing themselves, but also to her own need to heal from the effects of historical and current experiences of racism. In addition, she found herself having to consider another dimension of her presence in Canada on the traditional lands of Aboriginal people. $\mathrm{Ng}$ writes convincingly of the racist and sexist roots that underpin the construction of Canada as a nation. This racism began in Canada with the interventions of Europeans convinced of their superiority ${ }^{x i}$ to Indigenous peoples. ${ }^{x i i}$

It is this notion of relations that $\mathrm{Ng}$ emphasizes in her considerations of race, class, and gender in Canada's transition to a nation. Building on $\mathrm{Ng}$ 's analysis, the student came to see herself in relation not simply to "White" people in Toronto, but in relation to all non-Aboriginal peoples who always already live in relation to Indigenous peoples and their lands, whether they are conscious of this historical fact or not. This student, if one were to consider conventional diasporic studies, could be seen as one whose ancestors have already been twice displaced - once from a country of origin in Africa and a second time from Jamaica to Canada. The lessons she learned presented her 
with thoughts of a third displacement as she came to see her place in relation to the people whose traditional land the city of Toronto is built upon. The longing for (a) home becomes triply complicated for people in situations comparable to hers. However it is by adding a consideration of the history of the place where she has ended up, particularly in relation to the displacement of Indigenous people for the formation of the nation of Canada, that she was able to reach a deeper understanding of the complexities of her own situation and location here. Through such recognition - or perhaps through coming to know a more complete truth for the first time - the healing Knockwood seeks becomes a possibility for others within a colonized country.

\section{Beyond Binary Formulations}

The second event was precipitated by Professor Warren Crichlow, my colleague in the Faculty of Education with whom I team taught the seminar, Research and Issues in Language, Culture and Teaching, one of the two required courses students take in our doctoral program. Again, starting the class with considerations of land and Aboriginal people, I rather provocatively referred to two groups of people who currently live in Canada: those of Aboriginal ancestry and those of immigrant ancestry, more simply put, Aboriginal people and immigrants. For my purposes, positing this binary opposition was an effort to force a predetermined answer to the question I have since seen posed by Clifford, "How many generations does it take to become indigenous?" In my conversations with Warren, he gently pushed me to see that such binary formulations are far too reductive and disrespectful even for the sake of discussion.

I began to see how offensive and really unfair they are to people who came to this continent in ways which, while not unrelated to colonization-we cannot escape the endless march of capital across the globe-did not implicate them in the same ways as those who came with the clear intention of exploitation for profit. Many people came for better lives, to escape war and famine, to seek freedom, to start anew in a country that was advertised as terra nullius, empty land, there for the asking. They came through being enticed by those who were finding the First Nations labour force less than cooperative and who were seeking to occupy "Indian" lands as a way of claiming them and their resources while simultaneously developing a market for the goods Europe was producing. Tied to social Darwinism and its misguided notion of a hierarchy of the "races of man" was the conviction that First Nations people-Indians-were a vanishing race. Slavery and the slave trade, another of the evil practices that arose out of European notions of racial hierarchy and greed, forced many people to this continent. This Diaspora can hardly be collapsed with the situation of the people who forcibly took them from their homeland through what Dionne Brand has called the "door of no return." She writes,

But to the door of no return which is illuminated in the consciousness of Blacks in the Diaspora there are no maps. This door is not mere physicality. It is a spiritual location. It is also perhaps a psychic destination. Since leaving was never voluntary, return was, and still may be, an intention, however deeply buried. There is as it says no way in; no return.

In the course I taught with Warren, we read Toni Morrison's Playing in the Dark, a provocative text that argues that what has been considered the canon of great American 
literature - i.e. that written primarily by White people - most often operates in a context where an Africanist presence serves to "ignite critical moments of discovery or change or emphasis in literature not written by them." (Morrison viii). In other words, the presence of African-Americans is essential to the narratives but even as the authors use their existence to advantage, they never openly acknowledge their presence as central to the very substance of the work from plot to characterization and context.

Here I caution Canadian readers from excusing themselves from this discussion too quickly on the grounds that Morrison is examining American literature. While there may be nuances to the points being made, when one considers a Canadian context, there are enough resonances for them to be worth considering. While the formation of the United States has many distinctions from the formation of Canada, at least one thing exists in common. Both nations were created as an overlay to the many Indigenous nations whose lands became the basis of each country. While the canon of Canadian literature may acknowledge non-Whites more explicitly than those Morrison interrogates, all too often these characters also serve simply as foils for White epiphanies. They remain a shadowy presence or a presence fading to invisibility, too rarely being worthy of being the focus of critical analysis. That being said, the significance of slavery and the civil war in the United States do set up particular tensions different from Canada's, but still related to and informative to a critical view of Canadian history and its place in the literature. Morrison focuses on the diasporic (without naming it that) presence of slaves and then freed people as fundamental to the ways that White Americans have constructed themselves in their literature. Furthermore, she demonstrates with incisive clarity how literary critics have refused to engage seriously with this phenomenon. "The habit of ignoring race is understood to be graceful, even generous" (Morrison 1992:9). The Diaspora shall not be named.

As I considered theories of Diaspora and as I read and reread her text in writing this essay, I was struck by a number of things. First of all, as Warren had indicated, to divide the world of North America easily into immigrants and Aboriginal people is to do epistemic violence to many people who are now on this continent. Second, many aspects of Morrison's arguments give us new ways to think about the construction of White American literature in relation to Black America and its role in the development of the nation. But more perversely, I found myself wanting to take the critical model that Morrison establishes so eloquently and convincingly and turn it back on itself. I want to ask similar questions about the absent presence of Native Americans in the construction of America as the land of freedom from oppression, whether in the claims made by the original nation-builders or in those related to slavery and emancipation. My thoughts resonated with those of the teacher education student above who for years did not understand that the roots of Canada and its racism are based in Indigenous lands and peoples. Over the duration of the course, she came to understand her place in relation to indigeneity in Canada. Her personal journey took her to deeper understandings of the impact of racialization on her own life and on the larger society including the harm done in the name of race. In contrast, a refusal by diaspora theorists to engage with indigeneity re-creates the invisibility of the peoples who first occupied the lands that now form these nations. The very construction of a diasporic discourse in the U.S. holds a certain irony when it fails to see the oppression of Native Americans as integral to the formation of both the nation and inexticably related to the many Diasporas now there. 
Further examination of some of the points Morrison makes shows their commensurability with considerations of the place of Indigenous peoples throughout what is now called North America. In some of the following quotations, I found myself expecting and then often substituting the word Indigenous for the word Africanist or African-American and making good sense of the statements. In others, the claim held equally true for Indigenous-White relations and Black-White relations. As becomes quickly evident, her claims about literature have significant implications for discourses of Diaspora. While she is talking about American literature, she also focuses more generally on the ways that literary critics do not take up questions of race in their analyses. Herein lies another question for all readers of this essay: What questions do we ask or fail to ask in our own research that contributes to the erasure of racial "minorities"xiii from consciousness? I quote at length from her book in order to demonstrate how frequent are the possibilities for making direct comparisons between her argument and mine. I do not spend time explicating each quotation, but rather leave it to the reader to make the connections to his or her context. For me the connections to my context were clear. She writes:

Just as the formation of the nation necessitated coded language and purposeful restrictions to deal with the racial disingenuousness and moral frailty at its heart, so too did the literature...Through significant and underscored omissions, startling contradictions, heavily nuanced conflicts, through the way writers peopled their work with the signs and bodies of this presence - one can see that a real or fabricated Africanist [read Indigenous] presence was crucial to their sense of Americannness. And it shows. (Morrison 1992: 6, my emphasis)

Urgently needed is the same kind of attention paid to the literature of the western country that has one of the most resilient Africanist [read First Nation/Native American] populations in the world - a population that has always had a curiously intimate and unhingingly separate existence within the dominant one. (Morrison 1992: 12, my emphasis)

Like thousands of avid but non-academic readers, some powerful literary critics in the United States have never read and are proud to say so, any African-American [read First Nation/Native American] text. It seems to have done them no harm, presented them no discernible limitations in the scope of their work or influence. (ibid: 13)

I began to see how the literature I revered, the literature I loathed, behaved in its encounter with racial ideology. American literature [read Canadian] could not help being shaped by that encounter. (ibid: 16)

[I]mages of blinding whiteness seem to function as both antidote for and meditation on the shadow that is companion to this whiteness - a dark and abiding presence that moves the hearts and texts of American literature with fear and longing. (ibid: 33 ) 
Although the subtitle of Morrison's book is "Whiteness and the Literary Imagination," within the text, her focus on whiteness in relation almost exclusively to blackness misses the fundamental relation of both to Indigeneity. Here I turn her argument back on itself. Only at one point does she explicitly acknowledge an Indigenous population and then almost immediately dismisses its significance.

[A]bsolute power [is] called forth and played against and within a natural and mental landscape conceived as a "raw, half-savage world."

Why is it seen as raw and savage? Because it is peopled with a nonwhite indigenous population? Perhaps. But certainly because there is ready to hand a bound and unfree, rebellious but serviceable, black population. (ibid: 45)

I write of this absence not to try to diminish in any way the deeply thoughtful, innovative, and theoretically impressive work that Morrison has done. ${ }^{\text {xiv }}$ Rather, I want to make the point that, just as this text of hers does, to focus on the people of the Diasporas in North American (and other) contexts is too often to lose sight of the land and people of the place to which they are dispersed. In this blindness, the efforts at cultural genocide exemplified by residential schools and land grabs are reinscribed. As Morrison herself writes, similarly, by avoiding an overt discussion of slavery and "race" in America, "One could be released from a useless, binding, repulsive past into a kind of history-lessness, a blank page waiting to be inscribed" (ibid: 35). Settler Canadians, in their schools and in their everyday lack of consciousness, create the conditions that allow them the same possibility of forgetting their pasts and their relation to Indigenous peoples. While it may not be the intention of those who advocate getting on with the present and not spending time "dwelling" on the past, as is amply clear in the testimonials of those who have perpetrated racist acts and those who have felt their impact, intentions are not the determining factor in perpetuating racism and its discourses. Continued refusal to acknowledge the injustices committed historically and currently in the name of colonization and nation-building leads us to a state of blindness and denial. As scholars, these are not the usual places to which we aspire.

\section{Decolonizing Autobiographies}

The third pedagogical event I want to focus on brings us back to the university classroom for another consideration which spoke to me of the idea of decolonizing diaspora and a further move with the potential to inform all who currently dwell in colonized lands. First the context of this event: Antiracist pedagogy is an effort to address issues of race and racism overtly in classrooms. Although it has the potential to engage students with coursework in intense ways, I have often found taking it up in teacher education classes cut discussion short. White students got defensive and students of colour got rightfully angry with them. Clearly my approach could not get at the ways that people were making sense of their relations to one another and rather than create a forum for discussion, I was creating intransigence. As Stuart Hall wrote some years ago, "You can no longer conduct black [for my purposes, anti-racist] politics through a strategy of a simple set of reversals, putting in the place of the bad old essential white subject, the new 
essentially good black subject." (1996:444) To take up the complexity of a politic and practice to address racism, I had to find another approach.

Reading Linda Tuhiwai Smith's text Decolonizing Methodologies and Ania Loomba's Colonialism/Postcolonialism with graduate classes provided me some more interesting and productive ways to intervene in everyday understandings of race and racism. These works allowed me to build on some other ideas which have been central to my research and teaching. Taking for granted that reflexivity in research (Hammersley and Atkinson 1995) ${ }^{\mathrm{XV}}$ and starting from one's own experience in education (Freire 1971; Gore $1993: 13)^{\mathrm{xvi}}$ are methodologically and pedagogically sound, I began working with students to have them construct what I call decolonizing autobiographies as their introduction to a graduate course in decolonizing research methods. Inextricably tied to this work is the consideration that the physically embodied and historically located self of the researcher is always an integral part of any research s/he conducts. While there are still some people who chose to hide their particular reasons for doing research, the possibility of impartiality and objectivity has been thoroughly interrogated and found wanting when one takes context into account. For example, it turns out that the person conducting research on protein transmitters has a mother who died of cancer and somewhere in her head is the notion that this research has the potential to play a part in helping people in her mother's situation. ${ }^{\text {xvii }}$ As Clifford has commented, about the inclusion of what he calls "personal explorations....I include them in the belief that a degree of self-location is possible and valuable, particularly when it points beyond the individual toward ongoing webs of relationships" (1997:12). I ask people to think first about their relation to the land they are on at that moment. Although for many people living there, it is much more than simply a physical space, it does exist as a material entity. I tell them a story about the land. I ask them to imagine a sophisticated archaeological machine which would allow us to see down through the layers of earth on which we currently stand. The traces of many footprints lie buried at various levels with recent ones evident on and near the surface of that land. Deeply buried, the first human ones are those of Indigenous people - some are made recently; some longer ago than most of us can imagine. Since those first tracks were made, other sets of footprints have walked at different times on the same ground, layers upon layers upon layers. Through colonization, Diaspora, and immigration, feet of non-Indigenous peoples have arrived in traditional First Nations territories. In the layers, somewhere, our prints and perhaps those of our ancestors are lying. Regardless, we are all here now walking around in relation to one another and to the land. To be in good relation, as Métis scholar Kathy HodgsonSmith (1997) writes, requires us to know one another, to acknowledge our relation now and historically to each other, to all things living and nonliving, especially to the earth that sustains us physically, intellectually, emotionally and spiritually.

Based on less-than-systematic study, my impressions are that this approach of asking students to make explicit their own stories of coming to be in this First Nations territory is making a difference to deep considerations of social and historical relations within the students' contexts, be they research, teaching or studying. The conversations which follow are thoughtful and open. The preservice student teacher from Jamaica written about above, in some ways, presented me with her decolonizing autobiography as a result of what she had read in class. In the doctoral seminar with Toni Morrison's work and Warren Crichlow's guidance, I moved a step further in my own understanding of my 
relation to this land. For this class, I made explicit what had been coming to the foreground for some as they read and thought through the meanings the texts had for them. Decolonizing autobiographies have become a part of most of my classes as we struggle to make sense of various aspects of education and teaching in Canada. For these classes, I use parts of my own decolonizing narrative as a model to introduce myself. Sometimes, I start with the canoe bay on the river bank of my childhood home. Here my father, born in England, parked the wood and canvas freight canoe that he used to pole us up the river on those amazing days when the water level was just right and the west coast rain had let up long enough for wet sunshine to light up the river. My father came to Canada from England at the age of eighteen after being expelled from Charterhouse where his grandfather was headmaster; my mother came from Seattle where I too was born as she left our Vancouver Island home to have her babies near her mother. My family taught me in ways that made me feel as if I always knew that that canoe bay was used by the Kwakwaka'wakw people in earlier times. I did not know how to express my questions about where they had gone, but I also accepted tacitly that the land was always already occupied. When I moved around the province and around the country, I made myself conscious of being in Musqueam, Secwepemc, Salish, Tsimshian and Anishinaape territories. Locating myself in relation to the relevant First Nation is fundamental to my self-definition as a non-Aboriginal person in Canada, in academe, as a researcher and teacher. None of these relations to Canada is simple: none of these considerations allows me to escape from being fully implicated in the continuing colonizing narrative that supports this nation of Canada. But acknowledging this relation and tracing its roots through personal narrative and family history may be a first step in the long journey of possibility for decolonizing. I try to lead my students to some understandings arising out of this self-consciousness.

Following my story in which I touch on specific aspects of my life in what we now call Canada, my roots and my relations with Indigenous peoples in a variety of contexts, students then introduce themselves through their own stories. Some make connections to First Nations territories on which they live or have lived and some become aware of what they don't know. Their stories of being Indigenous or of coming to Canada - and their family's stories - are varied and they both historicize and complicate any notions of what it means to be part of a colonized country. What does it mean? For each person, the answer must be taken up in relation to their own coming to or being in this place. Again the simple binary distinctions of colonizer/colonized or Indigenous/immigrant fail to address the range of ways that people are a part of this country. We have stories of how we came to be here: we need to trace those stories and our place in the process of colonization-whether it is as entrepreneur, refugee, Indigenous person, adventurer, or any one of a myriad of possibilities. None of the players in these stories escape the effects of colonization, but in each case, one takes the time to think through what these effects are and what their significance is. Resonating with current theorizing around Diaspora, I say again there is nothing simple in any these stories. As Werbner writes of Diasporas,

Although the experience of exile is, in the first instance, personal and individual, long term diasporas create collective literary genres, symbolic representations, historical narratives of loss and redemption, and practical forms of political 
alliance and lobbying that are uniquely theirs. They are embodied and perpetuated through communal celebrations and transnational economic and political connections that are often invisible to the wider society (2000:17).

Through acknowledging family trajectories in the class, we have been able to prolong and deepen our discussions of race, colonization, Diaspora, class, gender and decolonization in ways that expand rather than shut down what we have to say to each other. We struggle to talk and listen to one another while never losing sight that no matter what the story, no matter how many generations of people of immigrant or diasporic ancestry have been here, beneath all our feet is land which has existed and does exist first of all in relation to Indigenous people.

This explication of decolonizing autobiographies brings us to the final pedagogical event I want to take up in this article. It arises with one student's engagement with a decolonizing autobiography. In the class, he began to interrogate not only the diasporic routes - his father's family from China, through Guyana, and his mother from Ireland to Scotland - which took him to Kapuskasing, Ontario, Canada but he also interrogated his relation with and consciousness of (primarily a lack thereof) First Nations people in a town with an Anishinaabe name that means "Bend in the River." $\mathrm{He}$ followed this trajectory through in a thorough analysis in his thesis and moved successfully to doctoral work. At the University of Louisiana in Baton Rouge, one of the first things he did was to identify a Native American community in the area. After searching the web, he chose this one primarily because their website indicated that the elders were francophone and he is fluently bilingual. He drove there and made some initial contacts that led very quickly to attendance at a band council meeting of the United Houma Nation. ${ }^{\text {xiii }}$ His doctoral work, now published, ${ }^{\text {xix }}$ focused on the community, and he began contributing to their existing political struggles as he conducted his work. Having focused on his own decolonizing narrative, he was in a position to listen to and learn from others. In his response to an earlier version of this article, he wrote, "Not until being asked to consider my relationship to the land and the original people who live on it was I able to learn how to listen and therefore learn differently." ${ }^{\text {xx }}$ While his roots in Canada can be distinguished as diasporic, it is his current relationship to the land and Aboriginal peoples which has led him to deepening awareness of the meaning of his diasporic existence.

\section{Decolonizing Diaspora}

These three pedagogical events and the courses I teach from which they arise have given me food for thought as I pondered the significance of the notion of diaspora. It remains my conviction that complicating understandings of Diaspora with considerations of lands and Indigenous peoples promises fuller, richer and more complex theory. Such a starting point provides a place for thinking through our relations to one another differently than if we ignore notions of Diaspora and complex comings to North America. I was doing just that in the doctoral class. Too often Diaspora theory ignores the presence of Indigenous peoples who were already in place when the first and the last diasporic peoples were forced or chose to come to a land. Continuing immigration in many countries augments the possibility of perpetuating ignorance as long as the nation 
fails to posit history in relation to the first peoples of the place. When will a citizenship exam ask whose traditional land one is moving on to as a way to begin to redress the attempted erasures of Indigenous people from the lands? And while it may be clear that every research in the area will not emphasize such a focus, in the same way that race, gender, and class analysis are addressed in some way in current critical scholarship, historicization of lands and the current place of Aboriginal people can come to be part of more thoughtful research. As J. Edward Chamberlin claims in his recent book, If This is Your Land, Where are Your Stories? it is time to reimagine "them and us," to move beyond simple binaries and complicate ways of thinking about people and places in all their complex relations with each other.

At this point, I return to the notion of Diaspora. Such a proposition - to maintain the visibility of the original peoples of a land - is not made lightly. The trauma of forced dispersal under any circumstances can fill the consciousness of those involved. But to ignore the trauma of those people who have been displaced here to make room, first for the colonizers and then for those who came after under all sorts of the other conditionsfrom slavery to starvation to war to straightforward immigration for the promise a "new world"-is to perpetuate what Gayatri Spivak has called epistemic violence. This violence is deeply ensconced in too much of our knowledge production, as is exemplified within university classrooms and on library shelves. To ignore their displacement is to reinscribe the erasure of Indigenous peoples from the lands and from the histories in ways similar to those of dominant colonizers. I reiterate the question with which we began: In diasporic theory, what does it mean to take seriously not only the land from which one comes, but the land and original people of the place where one arrives? As Werbner has pointed out in relation to current Armenian lobbies in the U.S.-following the establishment of the post-Soviet state of Armenia - "the contemporary Armenian diasporic political battle is a symbolic one: to inscribe Armenian suffering in the collective memory of a world community" (2000:17). While struggles of Indigenous peoples in Canada and the USA are usually much more than a symbolic effort, inscribing the injustices they have experienced for the past 500 years - and their resilience-in the collective memory of North Americans and, preferably, the world is one way to acknowledge and begin to redress the horrors perpetrated and to reimagine all our relations. 


\section{References}

Brand, Dionne. A Map to the Door of No Return: Notes to Belonging. Toronto: Doubleday Canada, 2001

Braziel, Jana Evans and Anita Mannur, eds. Theorizing Diaspora. Oxford: Blackwell Publishing, 2003.

Butler, Kim. "Defining Diaspora, Refining a Discourse." Diaspora-A Journal of Transnational Studies 2 (2001): 189-219.

Canada. Indian Treaties and Surrenders from 1680-1890. In two Volumes, Vol.1 Ottawa: Brown, Chamberlin, 1891.

Chamberlin, J. Edward. If This is Your Land, Where Are Your Stories? Finding Common Ground. Toronto: Knopf, 2003

Chrisjohn, Roland and Sherri Young. The Circle Game: Shadows and Substance in the Indian Residential School Experience in Canada. Penticton, B.C.: Theytus Books, 1997.

Clifford, James. Routes: Travel and Translation in the Late Twentieth Century. Cambridge MA: Harvard University Press, 1997.

Clifford, James. "Indigenous Articulations.” The Contemporary Pacific 2 (2001): 468490.

Dickason, Olive Patricia. Canada's First Nations: A History of Founding Peoples from Earliest Times. Toronto: Oxford University Press, 1992.

Freire, Paulo. Pedagogy of the Oppressed. New York: Continuum, 1971.

Furniss, Elizabeth. Victims of Benevolence: the Dark Legacy of the Williams Lake Residential School. Vancouver: Arsenal Pulp Press, 1992.

Glavin, Terry and Former Students of St. Mary's. Amongst God's Own: the Enduring Legacy of St. Mary's Mission. Mission, B.C.: Longhouse Publishing, 2002.

Gore, Jennifer. The Struggle for Pedagogies: Critical and Feminist Discourses as Regimes of Truth. London: Routledge, 1993.

Grant, Agnes. No End of Grief: Indian Residential Schools in Canada. Winnipeg: Pemmican Press, 1996.

Haig-Brown, Celia. Resistance and Renewal: Surviving the Indian Residential School. Vancouver: Tillacum Books, 1988. 
Haig-Brown, Celia and David Nock, eds. With Good Intentions: EuroCanadian and Aboriginal Relations in Colonial Canada. Vancouver: UBC Press, 2007.

Hall, Stuart. "New Ethnicities.” Stuart Hall: Critical Dialogues in Cultural Studies. Eds. D. Morley and K. Chen. London: Routledge, 1996. 441-449.

Hammersley, Martyn and Paul Atkinson. Ethnography: Principles in Practice. $2^{\mathrm{d}}$ ed. London: Routledge, 1995.

Hodgson-Smith, Kathy. Seeking good and right relations: Aboriginal student perspectives on the pedagogy of Joe Duquette High School. Unpbl. M.Ed thesis University of Saskatchewan, 1997.

Jaine, Linda, ed. Residential Schools: the Stolen Years. Saskatoon: University Extension Press, University of Saskatchewan, 1993.

Johnston, Basil. Indian School Days. Toronto: Key Porter Books, 1988.

Knockwood, Isabelle. Out of the Depths: The Experiences of Mi'kmaw Children at the Indian Residential School at Shubenacadie, Nova Scotia. Lockeport, N.S.: Roseway Publishing, 1992.

Lawrence, Bonita and Enakshi Dua. Decolonizing Antiracism. Social Justice Vol. 32, No. 4, pps. 120-143. 2005.

Loomba, Ania. Colonialism/Postcolonialism. London: Routledge, 1998.

Miller, James. Shingwauk's Vision: A History of Native Residential Schools. Toronto: University of Toronto Press, 1996.

Milloy, John. "A National Crime": the Canadian Government and the Residential School System, 1879-1986. Winnipeg: University of Manitoba Press, 1999.

Mirzoeff, Nicholas. Diaspora and Visual Culture: Representing Africans and Jews. New York: Routledge, 2000.

Morrison, Toni. Playing in the Dark: Whiteness and the Literary Imagination. New York: Vintage Books, 1992.

Morrison, Toni. Paradise. New York: Alfred Knopf, 1998.

Ng, Roxana. "Racism, Sexism and Nation Building in Canada." Race, Identity and Representation in Education. Eds. Cameron McCarthy and Warren Crichlow. London: Routledge, 1993. 50-59. 
Nicholas Ng-a-Fook. An Indigenous Curriculum of Place: The United Houma Nation's Contentious Relationship with Louisiana's Educational Institutions. New York: Peter Lang. 2007.

Roy, Parama. "At home in the world? The gendered cartographies of globality." Feminist Studies 3 (2001): 709-731.

Schmalz, Peter. The Ojibwa of Southern Ontario. Toronto: University of Toronto Press, 1991.

Smith, Linda Tuhiwai. Decolonizing Methodologies: Research and Indigenous Peoples. New York: Zed Books, 1999.

Werbner, Pnina. The Materiality of Diaspora-Between Aesthetic and "Real" Politics, Diaspora-A Journal of Transnational Studies 1 (2000): 5-19. 


\section{Endnotes}

Acknowledgements: I am very grateful to Professor Vijay Agnew, the Director of the Centre for Feminist Research who invited me to participate in the conference, "Diaspora, Memory and Silence: Who Calls Canada Home?" at York University in October 2003. This article is based on my presentation at that conference. I also want to thank Professor Nombuso Dlamini at the University of Windsor and Professor Cecille De Pass, former President of the Comparative and International Education Society of Canada, both of whom invited me to present versions of this paper to their constituents. I have benefited from comments made by them and members of those audiences. I am particularly grateful to my graduate students Nicholas Ng-A-Fook and Karleen Pendleton-Jimenez for their thoughtful critique. I am grateful to anonymous reviewers for their useful directives. Finally, I thank my partner Professor Didi Khayatt for her on-going support and input in all my scholarly pursuits.

\footnotetext{
i As always, a comment on terminology related to Indigenous peoples is necessary. The appropriate words are all hot political topics with rapidly changing connotations. At this time, I use the word Indigenous to refer to all peoples who have an articulated spiritual and material connection to a land they and their ancestors have occupied since time immemorial. First Nations refers (now) to a limited Canadian subset of people who associate themselves with the national body, the Assembly of First Nations. Aboriginal is used somewhat exchangeably with Indigenous, with the meaning "out of the original people." Some authors have different interpretations and find the word somewhat offensive. Native American is a generic term for the Indigenous peoples of the United States of America. Specific names of Indigenous nations such as Anishinaabe or Secwepemc are most appropriate as they are the current anglicizations of the words the people have for themselves. They too are in flux. In this case, language is on the move....

ii Throughout this section, I have used quotation marks to indicate concepts that really do not translate fully from various Aboriginal languages to English. While I realise that this may appear to be something of an obfuscation, it is actually intended to be a marker of the incommensurability of the concepts.

iii Most scholars have argued that in the early surrenders the Indigenous people were not aware of the full impact of their land cessions. They correctly argue that the Indian cultural perspective considered the land much like the air we breathe — given to all, but not specifically "owned" by anyone.

iv "For the 5,000 Iroquois refugees who congregated between the Genesee River and the Niagara, the British negotiated with the Mississauga, as they called the Ojibwa on the north shore of Lake Ontario, and purchased land along the Grand River in Upper Canada." (Dickason 1992:186-86)

${ }^{v}$ Interestingly, an Anishinaabe friend Mona Jones of Garden River First Nation referred to the area as a "breadbasket."

vi There are many annual gatherings of Aboriginal peoples in the area including the Canadian Aboriginal Festival held in November of each year. Of course, many of the Indigenous peoples who gather for the festival do not know the stories of this particular place and what it has given to the people since their creation stories and those that follow tell how they first appeared here.

${ }^{v i i}$ For one such discussion, see Bonita Lawrence and Enakshi Dua. (2005). Decolonizing Antiracism. Social Justice Vol. 32, No. 4, pps. 120-143.

viii See Ania Loomba (1998), 3 cf.

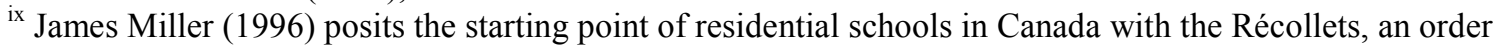
of the Franciscans, in 1620.

${ }^{\mathrm{x}}$ For examples of this work see Haig-Brown (1986); Johnston (1986); Furniss (1992); Knockwood (1992); Jaine (1993) ; Grant (1996); Miller (1996); Chrisjohn and Young (1997); Milloy (1999); Glavin and

Former Students of St. Mary's (2002).

${ }^{x i}$ Unfortunately, these attitudes persist to the present day particularly for those who feel they have a lot to lose if they recognize the debts owed and the immoral and illegal acts which have provided their secure
} 
lifestyles. See (or don't) Sir Albert Howard and Frances Widdowson (2008) Disrobing the Aboriginal Industry. Montreal: McGill-Queen's University Press. More importantly, read reviews by scholars such as Indigenous Governance Professor Taiaiake Alfred and Professor Charles Menzies at http://www.anthroblog.tadmcilwraith.com/2009/01/19/taiaiake-alfreds-review-of-widdowson-and-howardsdisrobing/ Accessed February 11, 2009.

xii It is important to note that there were Europeans who did not fit this characterization. Although they did not step outside the role of contributing to colonization through their particular presence in Indigenous territories, they recognized the richness of Aboriginal languages, the superior values in certain aspects of Indigenous cultural beliefs and practices as well as the injustice of the actions of many of the Europeans who were exploiting the resources and labour of the land and the First peoples. For more details of some of these individuals, see Celia Haig-Brown and David Nock, eds. (2007). With Good Intentions: EuroCanadian and Aboriginal Relations in Colonial Canada. Vancouver: UBC Press.

xiii Of course, racial minorities is a term with limited currency as the so-called minorities far outnumber people of European ancestry globally and in the near future will outnumber them in many countries which perceive themselves as dominantly "White."

${ }^{\text {xiv }}$ This oversight is fully addressed in Morrison's novel Paradise (1997) with First Nation/Native Americans playing a complex and significant role in the construction of the tensions and characters of the story. It begins in a convent "where Arapaho girls once sat and learned to forget" (Morrison 1997: 4).

${ }^{\mathrm{xv}}$ Reflexivity insists that researchers take seriously and make explicit their relationship to their work and the people with whom they engage.

${ }^{\text {xvi }}$ Starting from one's own experience in education suggests that teachers take the time to come to know their students' lives and capabilities, to present themselves to the students, and build their lessons and work together around these relationships of knowing.

xvii This example is taken from a conversation with a friend who is the researcher to whom I refer.

xviii I am very grateful to Nicholas Ng-A-Fook for his permission to use this story and for his careful review of an earlier version of this paper.

${ }^{x i x}$ Nicholas Ng-a-Fook. (2007). An Indigenous Curriculum of Place: The United Houma Nation's Contentious Relationship with Louisiana's Educational Institutions. New York: Peter Lang.

${ }^{\mathrm{xx}}$ Nicholas Ng-A-Fook. Personal communication. November 2003. 